care services. If this is the case, then our relative risks between periodontal disease and admission to hospital for coronary heart disease may underestimate the true risk.

The biological mechanism by which periodontal disease or poor oral hygiene could lead to coronary heart disease is not clearly established. The bacteria which cause periodontitis have been proposed as possible causative agents. ${ }^{1}$ Recent epidemiological studies have found that people with evidence of infection by Chlamydia pneumoniae have an increased risk of coronary heart disease. ${ }^{1516}$ The possibility that other bacteria, including those commonly associated with periodontal disease, may cause coronary heart disease is currently only theoretical. ${ }^{117} 18$

In conclusion, we found an association of coronary heart disease with periodontal disease and other measures of dental disease. Overall, the associations were weak, although not so weak in young men as to be dismissed as unimportant. Perhaps our most noteworthy finding, however, is that periodontal disease and poor oral hygiene are stronger indicators of risk of total mortality than of coronary heart disease. Oral health may be a more general indicator of personal hygiene and health care practices, including access to and use of health care services.

Dr Philip Graitcer provided valuable advice on the analysis plan.

1 Mattila KJ, Bieminen MS, Valtonen VV, Rasi RP, Kesaniemi YA, Syrajala $\mathrm{SL}$, et al. Association between dental health and acute myocardial infarction. BMF 1989;298:779-81.

2 Pooling Project Research Group. Relationship of blood pressure, serum cholesterol, smoking habit, relative weight and ECG abnormalities to incidence of major coronary events: final report of the pooling project. incidence of major coronary events. finat

3 National Center for Health Statistics. Decayed, missing, and filled teeth among persons 1-74 years: United States. Data from the National Health Survey. Hyattsville, Maryland: National Center for Health Statistics, 1981. (DHHS publication No (PHS)81-1673. Vital and health statistics; series 11; No 223.) 4 National Institute of Dental Research. Oral health of United States adults, the national survey of oral health in US employed adults and seniors: 1985-86. Bes Bethesda, Maryland: National

5 Gilmour H, Day E, Northridge

infarction. $B M 7$ 1989;298:1579-80. Mattila KJ. Dental health and acute myocardial infarction. BMf 1989;298: 1580

7 National Center for Health Statistics. Plan and operation of the health and nutrition examination survey: United States-1971-1973. Washington, DC: US GPO, 1977. (DHEW publication No (HRA) 77-1310. Vital and health statistics; series 1; No 10b.)

8 National Center for Health Statistics. Plan and operation of the NHANES I epidemiologic fellow-up study United States-1982-84. Washington, DC: US GPO, 1987. (DHHS publication No (PHS) 87-1324. Vital and health statistics; series 1; No 22.)

9 Madans JH, Kleinman JC, Cox CS, Barbano HE, Feldman JJ, Cohen B, et al. 10 years after NHANES I: report of initial follow up, 1982-84. Public Health Rep 1986;101:465-73.

10 Hopkins A. Survival analysis with covariates-Cox models. In: Dixon WJ, ed. BMDP statistical software manual. Los Angeles: University of California Press, 1988:719-44.

11 Miyazaki H, Pilot T, Leclercq M-H, Barmes DE. Profiles of periodontal conditions in adults measured by CPITN. Int Dent $f$ 1991;41:74-80.

12 DeStefano F, Ford ES, Newman J, Stevenson JM, Wetterhall SF, Anda RF, et al. Risk factors for coronary heart disease mortality among persons with diabetes. Ann Epidemiol 1993;3:27-34.

13 Stokes J III, Kannel WB, Wolf PA, Cupples LA, D'Agostino RB. The relative importance of selected risk factors for various manifestations of cardiovascular disease among men and women 35 to 64 years old: 30 years of following up in the Framingham study. Circulation 1987;75 (suppl V):65-73.

14 Posner BM, Cobb JL, Belanger AJ, Cupples LA, D'Agostino RB, Stokes J III. Dietary lipid predictors of coronary heart disease in men. Arch Intern Med 1991;151:1181-7.

15 Thom DH, Grayston JT, Siscovick DS, Wang S, Weiss NS, Daling JR Association of prior infection with Chlamydia pneumoniae and angioAssociation of prior infection with Chlamydia pneumoniae and angio-

16 Saikku P, Leinonen M, Tenkanen L, Linnanmaki E, Ekman M, Manninen V, et al. Chronic Chlamydia pneumoniae infection as a risk factor for coronary heart disease in the Helsinki heart study. Ann Intern Med 1992;116:273-8.

17 Lopes-Virella MF, Virella G. Immunological and microbiological factors in the pathogenesis of atherosclerosis. Clin Immunol Immunopathol 1985;37: 377-86.

18 Mattila KJ. Viral and bacterial infections in patients with acute myocardial infarction. F Intern Med 1989;225:293-6.

(Accepted 16 December 1992)
Department of Public

Health Sciences, St

George's Hospital Medical

School, London SW17 0RE

A Esmail, senior registrar

London E3 5AP

S Everington, general

practitioner

Correspondence to:

Dr A Esmail, Department of General Practice, University of Manchester, Rusholme

Health Centre, Manchester M14 5NP.

$B M \mathcal{F}$ 1993;306:691-2

\section{Racial discrimination against doctors from ethnic minorities}

\section{A Esmail, $S$ Everington}

A retrospective study of 1500 doctors graduating from five British medical schools between 1981 and 1987 suggested that those from ethnic minorities experienced disproportionate difficulty in obtaining hospital posts. ${ }^{\prime}$ A report published by the Commission for Racial Equality in 1987 also suggested that British trained doctors from ethnic minorities had trouble in getting the best jobs. ${ }^{2}$ Definitive evidence of discrimination, however, may be obtained only from a prospective study.

\section{Subjects, methods, and results}

A pilot study was carried out to test the hypothesis that British trained doctors with foreign sounding names were less likely to be shortlisted. We developed a curriculum vitae (CV) for six equivalent applicantsthree with Asian names and three with English names. All applicants were male, the same age, and educated and trained in Britain, with a similar length of experience in district general or teaching hospitals. All were at the same stage of their career, applying for their first senior house officer post in a non-teaching hospital because applications to teaching hospitals usually require completion of a form. Each $\mathrm{CV}$ was tailored to a particular post by including a short paragraph explaining why the candidate was applying for the job. The medical school and secondary education were randomly changed so that shortlisting was not influenced by attendance at a particular school or university. The pairs of names used for each application were randomly selected from the panel of three Asian and English applicants. The comparability of the CVs was confirmed by two consultants who were unaware of the purpose of the research and were asked to rate the CVs after the names had been removed.

Matched pairs of applications were sent for each post - one with an English name and one with an Asian name. The main outcome measure was the difference in the applicants' frequency of being shortlisted. When applicants were shortlisted we immediately cancelled any interviews.

We sent 46 applications for 23 advertised posts in otolaryngology, paediatric medicine, general surgery, psychiatry, and geriatric medicine. Eighteen applicants were shortlisted, of whom 12 had English and six Asian names (11 English and 17 Asian applicants were not shortlisted). In one post the English applicant was shortlisted and was subsequently withdrawnafter which the Asian applicant was shortlisted. This was included as a positive outcome for the English applicant.

The table shows the number of pairs where neither

Outcome of applications (pairs of English and Asian applicants shortlisted)

\begin{tabular}{|c|c|c|c|c|}
\hline & & \multicolumn{2}{|c|}{$\begin{array}{l}\text { English applicants } \\
\text { shortlisted }\end{array}$} & \multirow[b]{2}{*}{ Total } \\
\hline & & Yes & No & \\
\hline $\begin{array}{l}\text { Ethnic minority applicants } \\
\text { shortlisted }\end{array}$ & $\begin{array}{l}\text { Yes } \\
\text { No }\end{array}$ & $\begin{array}{l}6 \\
6\end{array}$ & $\begin{array}{r}0 \\
11\end{array}$ & $\begin{array}{r}6 \\
17\end{array}$ \\
\hline Total & & 12 & 11 & 23 \\
\hline
\end{tabular}

McNemar's test for matched pairs: $\chi^{2}=4 \cdot 17, p=0 \cdot 03, \mathrm{df}=1$ (with continuity correction). 
candidate was selected, where only the English candidate was selected, and where both were selected. The Asian candidate was never shortlisted unless the English candidate was also shortlisted. The outcome was different in six pairs $\left(\chi^{2}=4 \cdot 17, p=0.03, d f=1\right)$.

\section{Comment}

We originally planned a survey covering approximately 100 posts and all hospital specialties; unfortunately we were arrested by the fraud squad and charged with making fraudulent applications. Although not prosecuted, we were advised against continuing the work. Nevertheless, our results are important and suggest that discrimination does take place against ethnic minorities, apparently at shortlisting. English applicants were twice as likely to be selected, and this difference would probably have been greater had we carried out the full study and been able to include posts in teaching hospitals. Doctors from ethnic minorities predominate in at least two of our chosen specialties (psychiatry and geriatric medicine)-reflecting these specialties' comparative unpopularity ${ }^{3}$-and the proportion of such doctors is much greater in district general hospitals than in teaching hospitals. ${ }^{2}$ It is remarkable therefore that despite these two biases we still found a twofold difference.

Mechanisms could easily be incorporated to reduce the chance of name and ethnicity determining the likelihood of being shortlisted, as well as to monitor discrimination. As a start, we suggest that all application forms for medical posts should be standardised so that information identifying ethnic origin can be removed by the personnel department-for example, on a detachable front sheet. Ethnic monitoring should also be standard personnel practice so that all districts and regions can monitor whether equal opportunity policies are actually being implemented.

The research was commissioned and supported by the Medical Practitioners Union, 50 Southwark Street, London SE1 5UN.

1 McKeigue PM, Richards JDM, Richards P. Effects of discrimination by sex and race on the early careers of British medical undergraduates durin 1981-7. BMF 1990;301:961-4

2 Anwar M, Ali A. Overseas doctors: experience and expectations. London: Commission for Racial Equality, 1987.

3 Community Relations Commission. Doctors from overseas: a case for consultation. London: CRC, 1976

(Accepted 21 fanuary 1993)

\title{
Communication between general practitioners and child psychiatrists
}

\author{
Peter L Cornwall
}

Department of Child and Family Psychiatry, Sunderland District General Hospital, Sunderland SR4 7TP

Peter L Cornwall, registrar

$B M F$ 1993;306:692-3
Previous studies have examined the content of referral letters from general practitioners to consultants as well as the requirements of consultants. ${ }^{1-4}$ Child psychiatrists have a special interest in information about the child's family, as often the whole family will attend for assessment. This study aimed to review the content of referral letters from general practitioners to a child psychiatry department and to discover whether general practitioners and psychiatrists hold different views on the information that should be included in a referral letter.

\section{Methods and results}

From a consecutive series of 50 referral letters sent by general practitioners in Sunderland to the local department of child psychiatry, 15 items of information were identified that could account for all the information contained in the letters. The frequency with which each item appeared in the letters was recorded. Postal

Information contained in referral letters from general practitioners of department of child psychiatry

\begin{tabular}{lcc}
\hline & $\begin{array}{c}\text { No (\%) of } \\
\text { sample letters } \\
(\mathrm{n}=50)\end{array}$ & $\begin{array}{c}\text { Agreement between } \\
\text { GPs and psychiatrists } \\
\text { about importance of } \\
\text { items }\left(\chi^{2}, \mathrm{df}=3\right)\end{array}$ \\
Item & $46(92)$ & $3 \cdot 5$ \\
Presenting symptoms and problems & $20(40)$ & $10^{\star} \cdot 9^{\star}$ \\
History of presenting problems & $19(38)$ & $2 \cdot 4$ \\
Composition of the family & $18(36)$ & $3 \cdot 2$ \\
Past medical and psychiatric history & $12(24)$ & $7 \cdot 6$ \\
Personal history including development and schooling & $11(22)$ & $15 \cdot 3^{\star \star}$ \\
Assessment of family dynamics and relationships & $9(18)$ & $8 \cdot 9^{\star}$ \\
Attitude of the family to referral & $9(18)$ & $5 \cdot 4$ \\
Provisional diagnosis & $9(18)$ & $0 \cdot 5$ \\
Drug history including recent treatment & $8(16)$ & $2 \cdot 9$ \\
Reason for and urgency of referral & $8(16)$ & $16 \cdot 0^{\star \star}$ \\
Whether other agencies are involved & $5(10)$ & $4 \cdot 9$ \\
Family medical and psychiatric history & $4(8)$ & $16 \cdot 0^{\star \star}$ \\
Assessment of mental state of child & $4(8)$ & $3 \cdot 0$ \\
Physical assessment of the child & $4(8)$ & $2 \cdot 3$ \\
Information and advice given to the family & & \\
\hline
\end{tabular}

${ }^{\star} \mathrm{p}<0.05,{ }^{\star \star} \mathrm{p}<0.01$. questionnaires were then used to seek the views of local general practitioners and the child psychiatrists working in the Northern region. They were required to assess the importance of the 15 categories of information on a four point scale (categories of essential, desirable, doubtful, and irrelevant). They were also asked their views on the quality of referral letters in general.

Questionnaires were returned by $93(63 \%)$ general practitioners and $26(90 \%)$ psychiatrists. The table shows the frequency with which the 15 items of information occurred in the letters and the comparison of the importance given to the different items by the psychiatrists and the general practitioners.

The reason most often mentioned by general practitioners for poor quality letters was lack of time. A few replies contained the comment that families were sometimes reluctant to reveal information to their doctor. The main complaint from psychiatrists was that referral letters were too brief, with key information (particularly the attitude of the family to the referral and to involvement of other agencies) often absent.

\section{Comment}

Although the categorisation of information from referral letters is somewhat arbitrary, the study has the advantage that the items which the two groups of doctors were asked to assess were taken from a sample of actual letters. The study, moreover, replicates the finding by Kentish $e t$ al that the only item of information which is found consistently in referral letters is a description of the presenting symptoms. ${ }^{3}$ There was some consensus about the relative importance of certain items of information that a referral letter should include, but psychiatrists rated two key items of information of more importance: the attitude of the family to referral and whether other agencies are involved.

The attitude of the family has implications for the style of initial assessment carried out by the psychiatrist; if the psychiatrist realises from the outset that other agencies are involved then consent of the family for reports may be obtained at an early stage. Many general practitioners seem unaware of the importance for the psychiatrist of possessing this information before the family attends for the first appointment. It also seems that psychiatrists are 